\title{
Career guidance conceptualization to improve career adaptability for generation $z$
}

\author{
Aisha Nadya* \\ Universitas Islam Syekh Yusuf Tangerang \\ email: aishanadya@unis.ac.id \\ Muh Farozin \\ Universitas Negeri Yogyakarta \\ email: farozin@uny.ac.id
}

Received: April 06, 2021; Revised: April 26, 2021; Accepted: May 10, 2021

\begin{abstract}
Generation Z will control $20 \%$ of the workplace. Every generation has a different approach to work and the workplace. $Z$ generation needs to have career adaptability to anticipate problems such as worries about not getting a job and a lack of understanding about the desired field of work. The research aims to explore and create a solid theoretical foundation for designing a career guidance model to increase the adaptability of Generation Z's career. The research uses library research methods sourced from books and literature on 1) career adaptability, 2) understanding generation Z,3) counselling guidance models in the revolutionary era 4.0. The comparison between Generation $Z$ characteristics and the dimensions of career adaptability, the primary need of Generation $Z$ is career control. Career guidance services for Generation $Z$ can be in the form of 1) coaching, 2) workshops, 3) inspirational content through social media, 4) internship programs.
\end{abstract}

Keywords: career guidance, adaptability, generation ₹.

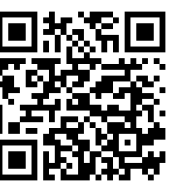

This is an open-access article under the CC-BY-SA license.

\section{Introduction}

After the millennials generation, today's industrial world is filled with the $z$ generation or the net generation. Generation $\mathrm{Z}$ is a group of individuals born after 1995, are productive workers and are starting their careers in the world of work. Some others are students and students who are planning a career to enter the industrial world. It is estimated that by 2020, Generation Z will dominate 20\% of the workplace (Dwidienawati \& Gandasari, 2018). Generation $Z$ is currently $18-29$ years old. These age ranges are categorized as adolescence and early adulthood (Papalia, Olds \& Feldman, 2007; Santrock, 2007). In this age range, individuals experience two transition periods in terms of careers. The first is the transition from high school to college. Second, the transition from university to the world of work. 
Every generation has a different approach to work and the workplace. Based on Bascha's study (Singh \& Dangmei, 2016), Generation Z prefers transparency, independence, flexibility and personal freedom as non-negotiable aspects of work ethics. The opposing sides of Gen- $Z$ in the world of work include the susceptibility to interpersonal conflicts, lack of productivity, low morale, and lack of involvement as employees. Other studies suggest that Gen-Z always expect to be notified, allowed to be retaliated against and that their responses are heard and acknowledged. Gen-Z job expectations generally expect a flexible workplace (Gaidhani et al., 2019).

Concerning Generation Z's expectations and expectations in the workplace, different work expectations and career orientations create conflict and frustration. Generation $\mathrm{Z}$ is known as a professional and ambitious generation. Hobby and passion are Generation Z's primary orientation in choosing a career. However, on the other hand, Generation $Z$ tends to be impatient; they want to establish quickly. The results of previous research stated that there was a shift in perceptions about Generation Z's profession and career, such as assuming that working in the creative industry is more profitable economically than working in the mining sector (Faisal, 2017). Unlike the previous generation, who considered being a doctor, lawyer, or architect as dream job.

The description above indicates the importance of career adaptability possessed by students as generation Z. Career adaptability is the readiness and ability of individuals to adapt and face changes in work and work situations (Ebenehi et al., 2016). The era of disruption allows changes to occur rapidly, both in work trends, work systems and work culture. Generation Z needs to get used to adjusting its work expectations with changes that may occur in the future.

One aspect of career adaptability is the ability to anticipate some of the problems that occur during the transition period (Alissa \& Akmal, 2019). Hartono \& Gunawan (2017) describe several career-related problems that are often experienced by Generation Z, including worries about not getting a job and not understanding the desired field of work. The first problem is also called career anxiety, caused by ignorance or lack of understanding of the desired field of work. Another cause is usually weak metacognitive abilities so that Generation Z does not know about self-potential and suitable career opportunities.

Another disparity that occurs in Generation $\mathrm{Z}$ is related to career adaptability, such as they generally do not know what benefits and abilities they learned in the major they chose while studying and their job prospects. The implication is that Generation $\mathrm{Z}$ will take guesswork in making career decisions. This phenomenon is in contrast to the ambition and passion that has been stated earlier.

Understanding the generational cohort is very important because educational institutions have a role and function in preparing superior humans and a bright future. Therefore, this study was conducted to find the concept of career guidance in higher education institutions that can help students have good career adaptability to have a bright future.

\section{Method}

This study uses a library research method, which is sourced from books and literature. The selected data sources are books and previous research journals (past ten years) that are relevant to 1) career adaptability, 2) understanding of generation $Z, 3$ ) counselling guidance models in the revolutionary era 4.0. The use of the literature review method aims to explore and create a solid theoretical foundation in designing career guidance models, which can be tested in the form of experiments in the future. The objectives of the literature review as described by Okoli \& Schabram (2015) are (1) providing a theoretical background/basis for the research to be carried out, (2) studying the depth or breadth of existing research related to the topic to be researched and (3) answering questions - practical questions with an understanding of what previous research has produced. 


\section{Findings and Discussion}

\section{Career Adaptability}

Career adaptability in the context of career development is an individual effort to overcome career development barriers. By the opinion of Hartung \& Cadaret (2017), career adaptability leads to individuals overcoming obstacles in career development tasks, job transitions, and work trauma. Career adaptability is the readiness and ability of individuals to adapt and face changes in work and work situations (Ebenehi et al., 2016).

This concept is also in line with Savickas opinion (Mardiyati \& Yuniawati, 2015) that the construct of career adaptability is a substitute construct for career maturity. Career adaptability refers to psychosocial constructs as unique resources to cope with and anticipate current tasks, transitions, a trauma in their job roles (Savickas \& Porfeli, 2012). Several studies have found that career adaptability plays an essential role in job performance, such as career satisfaction, promotion opportunities, job stress, job status, and job quality (Ye, 2015). Career adaptability is also predicted to increase life satisfaction in adolescents (Hirschi, 2009).

In career adaptability, four dimensions make a person more effective in carrying out his career, namely career concern, career control, career curiosity, and career confidence. These four dimensions represent common adaptive resources and strategies that individuals use to manage tasks, transitions, and critical trauma as individuals build their careers (Ramdhani \& Kiswanto, 2020). If a person has career adaptability, will have sensitivity and concern for the future, strive to manage oneself well, explore self-possibilities and future scenarios, and strengthen confidence to pursue career aspirations.

\section{Career Adaptability Dimensions}

The dimension of career adaptability needs to be studied as a reference for relevant guidance content in developing student career adaptability as Generation Z. In general, the four dimensions of career adaptability have been mentioned above, namely, career concern, career control, career curiosity, and career.

A detailed explanation of the four dimensions can refer to the Savickas concept (Lent \& Brown, 2012).

a. Career concern, relating to the belief of each individual in achieving his goals. A person who has career concerns will have a clearer view and have confidence in his future in realizing career planning.

b. Career control shows that individuals are responsible for building their careers. A person's belief in controlling his career has an impact on the way he makes career choices. Lack of career control confuses career determination leading to delays in completing each assignment.

c. Career curiosity is an aspect that makes individuals seek much information about the career they are interested in. Someone who has a high sense of career curiosity will be enthusiastic about choosing his career. Someone who has a low career curiosity will be unrealistic in facing his work life.

d. Career confidence manifested in confidence in making career decisions. Career beliefs arise from solving problems faced in everyday life, such as at home or on campus.

Concerning career guidance content, Sisca \& Gunawan (2016) created an operationalization matrix for each of these dimensions. The operating table for each dimension of career adaptability can be seen in Table 1 below. 


\begin{tabular}{|c|c|c|c|c|}
\hline Adaptability & Attitudes & Competence & Coping & Career Problem \\
\hline Concern & Well prepared & Make a plan & $\begin{array}{l}\text { Awareness } \\
\text { involvement Full } \\
\text { of preparation }\end{array}$ & $\begin{array}{l}\text { Ignorance } \\
\text { career }\end{array}$ \\
\hline Management & Establish & Make decisions & $\begin{array}{l}\text { Assertive } \\
\text { Dicipline } \\
\text { Motivated }\end{array}$ & $\begin{array}{l}\text { Indecision } \\
\text { career }\end{array}$ \\
\hline Curiosity & Curiosity & Exploration & $\begin{array}{l}\text { Dare to try } \\
\text { Take a risk } \\
\text { Keep Going }\end{array}$ & $\begin{array}{l}\text { Unrealistic } \\
\text { career }\end{array}$ \\
\hline Keyakinan & Manjur, efektif & $\begin{array}{l}\text { Pemecahan } \\
\text { masalah }\end{array}$ & $\begin{array}{l}\text { Persistensi } \\
\text { Penuh daya juang } \\
\text { Produktif }\end{array}$ & \\
\hline
\end{tabular}

Table 1. Career Adaptability Operationalization Matrix

Career guidance content can refer to the matrix above. The formulation of relevant content takes into account the competencies to be developed.

\section{Generation $\mathrm{Z}$ in Careers}

Generation Z was born after 1995 and spread until 2010 (Bascha, 2011; Brue Tulgan \& Rain maker Inc., 2013). Generation Z was born and raised on social media, centred on digital and technology is an identity that cannot be separated from them. (Dangmei et al., 2016). On the other hand, as a technology generation, they have challenges; namely, they lack problem-solving skills and have not shown the ability to see situations, put them in context, analyze them and make decisions (Joseph Coombs, 2013). In other words, they need help to critically evaluate online sources and learn how to process large amounts of information.

Teresa Bridges (2015) said that Generation Z prefers a work environment involving mentoring, learning, and professional development. For them, education is deemed not to provide the skills needed to face real-life problems. They see instructors as facilitators who help develop relevant and practical skills.

\section{Career Counseling Services for Generation Z}

Career guidance services in higher education are an information centre towards the world of work, designing careers and solving career-related problems (Subhan et al., 2019). In general, career guidance programs provide outreach to students about job trends that they can choose and are much needed. Furthermore, it can also provide an overview of the characteristics of Human Resources that are currently needed by the labour market.

Career guidance for Generation Z remains essentially the same. However, in service delivery and strategy, it is necessary to pay attention to the distinctive characteristics of Generation Z.

a. Generation $\mathrm{Z}$ is accustomed to looking for information by using the Google search engine in their daily lives and even accessing social media and using it to obtain learning materials, in line with a large number of social media presenting educational content.

b. The meaning of career for generation $Z$ is closely related to the social meaning of work, success and professionalism. Generation $Z$ tends to understand that success is something that looks good for themselves and others. Therefore they are delighted to upload their activities and daily activities as social media content 
c. Generation $\mathrm{Z}$ has designed their career plans from the start with their identity as their background. They seem optimistic and have passion. As stated by Bascha (2011) that generation $\mathrm{Z}$ likes transparency, independence, flexibility and personal freedom at work.

Based on the characteristics above, career guidance for Generation $\mathrm{Z}$ is an aid to strengthen and finalize career planning. Various content that will become services must be based on survey results regarding what is currently being liked and the dream of students. Remembering for Generation Z, Work-Life Balance is significant for career decisions (Kirchmayer, \& Fratričová, 2020).

Integration of service strategies with technology tools such as social media is necessary to increase service accessibility. Considering that generation $\mathrm{Z}$ as the internet generation is filled with their dependence on technology. (Berkup, S. B., 2014). In addition, collaboration needs to be carried out such as schools, universities, communities, and related institutions that can positively impact academic motivation and student experience.

\section{Career Guidance Service Concept in Improving Generation Z's Career Adaptability}

The comparison between the characteristics of Generation $Z$ and the dimensions of career adaptability, the immediate need of Generation $Z$ is career control. Generation $Z$ has a plan about what they want to do and get. However, they have not been able to anticipate obstacles, conflicts in the world of work, transitional periods, and uncertainties. Therefore Generation $\mathrm{Z}$ needs guidance and training to manage their career plans.

Career guidance services for Generation $Z$ can be in the form of 1) coaching, 2) workshops, 3) inspirational content through social media, 4) internship programs. The description of the service concept can be seen in Table 1 below.

Table 1. Career Guidance Service Concept for Generation Z

\begin{tabular}{ll}
\hline Strategics & Goals \\
\hline Coaching & $\begin{array}{l}\text { Fostering an assertive and disciplined attitude } \\
\text { towards career plans }\end{array}$ \\
\hline Workshop & $\begin{array}{l}\text { Increase curiosity and exploration of career } \\
\text { planning support skills }\end{array}$ \\
\hline Internship program & $\begin{array}{l}\text { Fostering the courage to try and increasing } \\
\text { resilience }\end{array}$ \\
\hline Social Media Content & Maintaining motivation toward a career choice \\
\hline
\end{tabular}

\section{Conclusion}

Generation $\mathrm{Z}$ has a plan about what they want to do and get. However, they have not been able to anticipate obstacles, conflicts in the world of work, transitional periods, and uncertainties. On the other hand, Generation Z has optimism in their careers. In line with that, career adaptation is associated with career optimism, self-esteem, hope, life satisfaction, and general well-being. (Cai et al., 2015; Douglass \& Duffy, 2015; Hirschi, 2009; Ohme \& Zacher, 2015; Santilli, Nota, Ginevra, \& Soresi, 2016).

Career guidance and counselling services should focus on creating a competitive curriculum. There needs to be a priority in providing the skills and competencies that graduates need to enter the job market in the future. In addition, there is an effort to integrate and strengthen soft-skill training for students. Career guidance services for Generation $\mathrm{Z}$ can be in the form of 1) coaching, 2) workshops, 3) inspirational content through social media, 4) internship programs.

\section{References}


Alissa, S., \& Akmal, S. Z. (2019). Career Decision Making Self-Efficacy Mediator Antara Dukungan Kontekstual dan Adaptabilitas Karier. Jurnal Psikologi Pendidikan \& Konseling: Jurnal Kajian Psikologi Pendidikan Dan Bimbingan Konseling, 5(1).

Bascha.(2011). Z: The open source generation. Retrieved from http://opensource.com/business/11/9/z-open-source-generation

Berkup, S. B. (2014). Working with Generations X and Y in Generation Z Period: Management of Different Generations in Business Life. Mediterranean Journal of Social Sciences. doi:10.5901/mjss. 2014.v5n19p218

Brue Tulgan\& Rain Maker Thinkign Inc. (2013). Meet Generation Z: The second generationwithin the giant "Millennial" cohort Rerieved from http://rainmakerthinking.com/assets/uploads/2013/10/Gen-Z Whitepaper.pdf.

Cai, Z., Guan, Y., Li, H., Shi, W., Guo, K., Liu, Y., \& Hua, H. (2015). Self-esteem and proactive personality as predictors of future work self and career adaptability: An examination of mediating and moderating processes. Journal of Vocational Behavior, 86, 86-94.

Dan Schawbel. (2014). Gen Z Employees: The 5 Attributes You Need to Know. Retrieved from http://www.entrepreneur.com/article/236560

Dangmei, Jianguanglung \& Singh, Amarendra. (2016). Understanding The Generation Z: The Future Workforce. 3. 1-5.

Dwidienawati, D., \& Gandasari, D. (2018). Understanding Indonesia’s Generation Z. International Journalof Engineering Dan Technology, 7(3).

Douglass, R. P., \& Duffy, R. D. (2015). Calling and career adaptability among undergraduate students. Journal of Vocational Behavior, 86, 58-65.

Ebenehi, A. S., Rashid, A. M., \& Bakar, A. R. (2016). Predictors of career adaptability skill among higher education students in Nigeria. International Journal for Research in Vocational Education and Training (IJRVET), 3(3).

Faisal, M. (2017). Generasi Phi: Memahami milenial pengubah Indonesia. Republika.

Gaidhani, S., Arora, L., \& Sharma, B. K. (2019). Understanding the attitude of generation Z towards workplace. International Journal of Management, Technology and Engineering, 9(1).

Hartono, R. M., \& Gunawan, W. (2017). Hubungan Job Search Self-Efficacy dengan Career Adaptability. Jurnal Ilmiah Psikologi MIND SET, 8(02).

Hartung, P. J., \& Cadaret, M. C. (2017). Career adaptability: Changing self and situation for satisfaction and success. In Psychology of Career Adaptability, Employability and Resilience. Springer, Cham.

Hirschi, A. (2009). Career adaptability development in adolescence: Multiple predictors and effect on sense of power and life satisfaction. Journal of Vocational Behavior, 74(2).

Joseph Coombs.(2013).Generation Z: Why HR Must Be Prepared for Its Arrival Retrieved from http://www.shrm.org/hrdisciplines/staffingmanagement/articles/pages/preparefor generation-z.aspx

Kirchmayer, Z., \& Fratričová, J. (2020). On the Verge of Generation Z: Career Expectations of Current University Students. Education Excellence and Innovation Management through Vision, 1575-1583.

Lent, R. W., \& Brown, S. D. (2012). Career development and counseling: Putting theory and research to work (2nd ed.). John Willey \& Sons.

Mardiyati, B. D., \& Yuniawati, R. (2015). Perbedaan Adaptabilitas Karier Ditinjau dari Jenis Sekolah (SMA dan SMK). EMP ATHY Jurnal Fakultas Psikologi, 3(1).

Ohme, M., \& Zacher, H. (2015). Job performance ratings: The relative importance of mental ability, conscientiousness, and career adaptability. Journal of Vocational Behavior, 87, 161-170.

Okoli, Chitu (2015). A Guide to Conducting a Standalone Systematic Literature Review. Communications of the Association for Information Systems (37:43), November 2015, pp. 879- 910. http://aisel.aisnet.org/cais/vol37/iss1/43 
Papalia, D.E., Olds, S.W., \& Feldman, R.D. (2007). Human Development. New York: McGraw Hill

Ramdhani, R. N., \& Kiswanto, A. (2020). Urgensi Adaptabilitas dan Resiliensi Karier pada Masa Pandemi. Indonesian Journal of Educational Counseling, 4(2).

Santilli, S., Marcionetti, J., Rochat, S., Rossier, J., \& Nota, L. (2016). Career adaptability, hope, optimism, and life satisfaction in Italian and Swiss adolescents. Journal of Career Development, 44, 62-76.

Santrock, J.W. (2007). Perkembangan anak. Jakarta: PT Erlangga

Savickas, M. L., \& Porfeli, E. J. . (2012). Career Adapt-Abilities Scale: Construction,reliability, and measurement equivalence across 13 countries. Journal of VocationalBebavior, 80(3).

Singh, A. P., \& Dangmei, J. (2016). Understanding the generation Z: the future workforce. SouthAsian. Journal of Multidisciplinary Studies, 3(3).

Sisca, S., \& Gunawan, W. (2016). Gambaran adaptabilitas karier remaja. Jurnal Psikologi, 11(2).

Subhan, M., Hasgimianti, Hasgimianti, Sari, W. P., Bakar, A. Y. A., \& Amat, S. (2019). Kematangan karier mahasiswa prodi ekonomi dalam pemilihan karier. Journal Educational Guidance and Counseling Development, 2(2).

Teresa Bridge. (2015). 5 Ways The workplace Needs To Change to Get The Most out Of Generation Z. Retrieved from http://www.fastcoexist.com/3049848/5-ways-theworkplaceneeds-to-change-to-get-the-most-out-of-generation- $z$

Ye, L. (2015). Work values and career adaptability of Chinese university students. Social Behavior and Personality, 43(3). 